\title{
IMPLEMENTASI PENDEKATAN SAINTIFIK TERHADAP KEMAMPUAN KOGNITIF SAINS ANAK USIA 5-6 TAHUN DI RA ANNUR ASSALAFY TUMPANG PACARKELING KEJAYAN PASURUAN
}

\author{
Putri Ismawati ${ }^{1}$, Hanifah ${ }^{2}$ \\ 1PIAUD STITNU Al Hikmah Mojokerto, ${ }^{2}$ PIAUD STITNU Al Hikmah Mojokerto \\ e-mail: ${ }^{1}$ putriismawati.pi@gmail.com, ${ }^{2}$ canayhanif@gmail.com,
}

Diterima: 5 Juni 2020

I Direvisi: 6 Juni 2020

I Disetujui: 9 Juni 2020

(C)2020 Pendidikan Guru Raudhatul Atfhal Fakultas Agama Islam Universitas Islam Malang

\begin{abstract}
This study aims to determine the effectiveness of the implementation of a scientific approach to the cognitive abilities of children aged 5-6 years at RA Annur Assalafy Tumpang Pacarkeling Kejayan Pasuruan. Using a scientific approach with 5M understanding (observing, asking questions, gathering information, reasoning/ associating, making conclusions and communicating) it is expected that the learning process in RA, especially in the cognitive development of science can attract the attention of children so that children's interest in learning is very good so that aspects of children's development can be achieved as expected. This study uses qualitative research that describes the understanding of researchers in implementing scientific approaches to the learning process, especially cognitive science. The data is obtained by interview, observation, and documentation. The results of his research are (1) The researchers' initial understanding of the cognitive approach to science is good enough. (2) Learning planning in a scientific approach in preparing the daily learning implementation plan (RPPH) and the media have referred to the appropriate steps. (3) The implementation of cognitive science learning by using a synthetic approach in preliminary activities, core activities, closing activities are good enough with an understanding of $5 M$ (observing, asking questions, gathering information, reasoning/associating, making conclusions and communicating).
\end{abstract}

Keywords: Scientific approach, Cognitive Science

\section{A. Pendahuluan}

Lembaga Pendidikan anak usia dini membuat kegiatan yang dapat menumbuh kembangkan berbagai aspek perkembangan seperti kegiatan yang bisa menumbuh kembangkan dalam aspek agama, kognitif,bahasa,sosial emosional,fisik motorik dan seni. Dalam penelitian ini perkembangan kognitif lebih di tekankan sehingga perlu adanya kegiatan kognitif yang menarik perhatian anak seperti kognitif sains. Karena pembelajaran sains pendidikan anak usia dini meliputi berbagai macam, bahkan semua aspek perkembangan bisa masuk dalam

This work is licensed under Creative Commons Attribution Non Commercial 4.0 International License Available online on: http://riset.unisma.ac.id/index.php/fai/index 
pembelajaran sains terutama kognitif. Dalam (PERMENDIKNAS 58 Tahun 2009) di jelaskan lingkup perkembangan bagian kognitif usia 5-6 tahun meliputi pemgetahuan umum dan sains, oleh karena itu pembelajaran pengetahuan umum dan sains ini cocok ketika di aplikasikan dalam pembelajaran sains dengan menggunakan pendekatan saintifik.Pembelajaran sains dalam kurikulum 2013 ini di terapkan dengan pendekatan saintifik agar memancing anak untuk berpikir. Kurikulum 2013 yang mencanangkan pendekatan saintifik di mana pendekatan saintifik ada lima unsur untuk melaksanakannya di antaranya mengamati, menanya, mengumpulkan informasi, mengolah informasi, dan menarik kesimpulan. Rumusan masalah dari permasalahan ini adalah bagaimana implementasi pendekatan saintifik terhadap kemampuan kognitif sains anak usia 5-6 tahun di RA Annur Assalafy. Sedangkan tujuan penelitian nya adalah penelitian implementasi pendekatan saintifik terhadap kemampuan kognitif sains anak usia 5-6 tahun di RA Annur Assalafy. Sedangkan manfaat penelitian secara teoritis dapat mengetahui metode pembelajaran yang baik, yang dapat di terapkan dalam pembelajaran anak usia dini. Sedangkan manfaat secara praktis bagi guru di harapkan dapat memberi masukan kepada guru tentang salah satu alternatif pembelajaran kognitif sains dengan pendekatan saintifik kepada anak dalam kegiatan pembelajaran. Anak akan lebih mudah memahami dan mengerti pembelajaran kognitif sains dengan menggunakan pendekatan saintifik sehingga kemampuan anak dalam aspek perkembangan kognitif sains anak akan meningkat.

Kognitif sains adalah kajian ilmiah tentang pikiran dan otak dan bagaimana prilaku dihasilkan. pembelajaran kognitif sains memungkinkan anak untuk bereksperimen terhadap berbagai benda baik beda hidup ataupun benda mati.Selain itu,dapat juga melatih anak untuk menggunakan panca indranya untuk mengenal berbagai benda dan peristiwa di sekitarnya. Sedangkan Pendekatan saintifik adalah proses pembelajaran yang di rancang oleh guru untuk membangn pemahaman anak melalui 5 tahapan (mengamati, menanya, mengumpulkan informasi, menalar/mengasosiasi, membuat kesimpulan dan mengkomunikasikan). Menurut (arissohiman,2014: 165) proses pembelajaran yang mengimplementasikan pendekatan saintifikakan menyentuh tiga rana, yaitu sikap (afektif), pengetahuan (kognitif), dan keterampilan (psikomotor). Dengan proses pembelajaran yang demikian di harapkan hasil belajar melahirkan peserta didik yang produktif, kreatif, inovatif, dan afektif melalui penguatan sikap , keterampilan, dan pengetahuan yang terintegrasi .

Teori Dyer yang menjadi dasar berkembangnya pendekatan saintifik (scientific apporoach) yang didalamnya terdapat komponen proses pembelajaran antara lain 1) Observing (mengamati), 2) Questioning (menanya), 3) Assocating 
(menalar), 4) Experimental (mencoba), 5) Networking (melakukan komukasi). (1) Observing (mengamati) adalah kegiatan awal yang di lakukan oleh peserta didik untuk pembelajaran. Pembelajaran mengamati bisa di lakukan oleh siapa saja, terutama anak usia dini. Pengamatan ini diawali dengan di perlihatkan suatu benda, setelah itu baru peserta didik mengamati benda tesebut. (2) Questioning (menanya) setelah peserta didik melakukan pengamatan, maka dengan rangsangan guru peserta didik akan melakukan pertanyaan, ketika pembelajaran yang ditampilkan oleh guru unik dan menarik anak akan tertantang untuk bertanya, bertanya untuk tingkat anak usia dini sama seperti orang dewasa, akan tetapi pertanyaan anak lebih dasar, ketika anak mampu bertanya semua yang diinginkan maka di katakan berhasil pembelajaran sains yang di lakukan oleh guru. (3) Assocating (menalar) istilah menalar menurut Daryanto (2014:71) kerangka proses pembelajaran dengan pendekatan ilmiah dalam kurikulum 2013 untuk menggambarkan bahwa guru dan peserta didik merupakan pelaku aktif. Setelah peserta didik mendapatkan pertanyaan dari jawaban dari pertanyaan yang di ajukan, maka anak akan menyimpulkan tentang benda tersebut. Ketika penalaran ini diaplikasikan dalam pendidikan anak usia dini memang membutuhkan kesabaran terutama bagi guru untuk menjelaskan. (4) Experimental (mencoba) untuk memperoleh hasil belajar yang otentik dan nyata maka dilakukan percoban, terutama materi yang sebelumnya dilakukan. Dalam pembelajaran anak usia dini sebagai contoh pembelajaran kognitif sains, percobaan terapung, mengmbang dan tenggelam maka anak akan mencoba secara langsung pembelajaran tersebut secara konkrit. (5) Networking (melakukan komunikasi) melakukan komunkasi ini adalah apa yang telah peserta didik coba kemudian disampaikan semua ilmu yang di dapat, mulai dari observasi hingga percobaan, komukasi ini akan menimbulkan ilmu yang berbeda, karena anak akan memberikan pendapat percobaan yang telah di lakukan.

Penelitian ini membutuhkan teori yang dapat mendukung dalam proses pengolahan data oleh karenanya pendekatan saintifik yang peneliti teliti ini memiliki teori yang sesuai dengan apa yang akan di teliti. Dalam Daryanto (2014:52) metode saintifik ini sangat relevan dengan tiga teori belajar (1)Teori belajar Bruner mengatakan teori belajar penemuan. Di dalamnya terdapat empat komponen yang berkaitan. Pertama, individu hanya belajar dan mengembangkan pikiran. Kedua, proses-proses kognitif dalam proses penentuan, siswa akan memperoleh sensasi dan kepuasan intelektual yang merupakan peghargaan intrinsik. Ketiga, memiliki kesempatan untuk melakukan penemuan. Keempat, dengan melakukan penemuan maka akan memperkuat retensi ingatan. (2) Teori piaget, menyatakan bahwa belajar berkaitan dengan pembentukan dan 
perkembangan skema, selain itu pembelajaran di perlukan adanya penyeimbangan atau ekuilibrasi antara asimilasi dan akomodasi. (3) Vygotsky, dalam teorinya menyatakan bahwa pembelajaran terjadi apabila peserta didik bekerja atau belajar menganani tugas-tugas yang belum di pelajari namun tugas-tugas itu masih berada dalam zone of proximal developmentdaerah terletak antara tingkat perkembangan anak.

Sumanto, 2007 yang di kutip Marjan, Aryan dkk (2012:02) dalam jurnal mengatakan pembelajaran sains merupakan cara mencari tahu tentang alam semesta secara sistematis untuk menguasai pengetahuan, fakta-fakta, konsepkonsep, prinsip-prinsip, proses penemuan, dan memiliki sikap ilmiah. pembelajaran sains yang di mana pembelajaran yang berfungsi untuk setiap individu bisa mempelajari dirinya sendiri dengan menganalisa, mengamati diri sendiri dan lingkungan sehingga mampu membuat formulasi untuk mengembangkan kehidupan yang akan dihadapi, hal tersebut berdasarkan hakikat dari sains (Marjan, Aryana dkk 2012:02). Pembelajaran sains merupakan pengetahuan sebab akibat dari alam semesta ini.Pengertian sains (ilmu pengetahuan) dalam Sujiono dkk (2008:12) mengatakan suatu objek bahasan yang berhubungan dengan bidang studi tentang kenyataan atau fakta dan teori-teori yang mampu menjelaskan tentang fenomena alam. Sementara itu, The Harper Encyclopedia of secience dalam Subiyanto (1988:3) menyebutkan bahwa ilmu pengetahuan dan pendapat yang tersusun dan tunjang secara sistematis oleh bukti-bukti yang formal atau oleh hal-hal yang di amati. Ilmu pengetahuan atau sains adalah ilmu yang membutuhkan bukti-bukti yang pasti dengan cara aplikasi langsung pengetahuan atau observasi, yang nantinya akan menghasilkan konsep baru. Sedangkan dalam suwarma, Poedjiadi (2012:2) Connan mengemukakan “ sains adalah serangkaian konsep dan skema konseptual yang di kembangkan sebagai hasil eksperimen dan observasi yang berguna bagi observasindan eksperimen selanjutnya.

Sujiono (2008:12) mengatakan secara khusus permainan sains di pendidikan anak usia dini bertujuan agar anak memiliki kemampuan (a) mengamati perubahan yang terjadi di sekitarnya (b) melakukan percobaanpercobaaan sederhana (c) melakukan kegiatan membandingkan, memperkirakan, mengklasifikasikan serta mengkomunikasikan tentang sesuatu sebagai hasil sebuah pengamatan yang sudah di lakukannya (d) meningkatkan kreatifitas dan inovasi khususnya dalam bidang ilmu pengetahuan alam, sehingga siswa akan dapat memecahkan masalah yang dihadapinya. Selain itu ada pandangan tokoh lain, tujuan pembelajaran sains di sekolah adalah sejalannya dengan kurikulum sekolah, yakni mengembangkan anak secara utuh baik aspek domain kognitif, 
aspek afektif maupun aspek psikomotor anak usia dini Crain dkk, dalam Garmiati (2014:35).

Menurut Suyanto dalam Yulianti (2010:26) pengenalan sains untuk pendidikan anak usia dini di lakukan untuk mengembangkan kemampuan sebagai berikut (a) eksplorasi dan investigasi yaitu kegiatan untuk mengamati dan menyelidiki objek dan fenomena alam. (b) mengembangkan keterampilan sains seperti melakukan pengamatan, mengukur, mengkomunikasikan hasil pengamatan. (c) mengembangkan rasa ingin tahu, rasa senang dan mau melakukan kegiatan penemuan. (d) memahami pengetahuan tentang berbagai benda baik ciri, struktur maupun fungsinya.Pengembangan sains untuk anak usia dini di lakukan melalui pengamatan, mengkmunikasikan hasil pengamatan, mengembangkan rasa ingin tahu dan menyimpulkan semua kegiatan yang di lakukan.

Konsep pembelajaran sains bisa dikatakan berhasil menurut Wisudawati, Sulistyowati ( 2014:11 ) seorang guru dikatakan berhasil dalam proses pembelajaran sains ketika guru mampu mengubah pembelajaran yang semula sulit menjadi mudah, yang semula tidak menarik menjadi menarik bagi anak. Konsep ini memang tidak semua orang mampu mengatasinya dengan mudah akan tetapi butuh waktu untuk pembiasaannya. Bentuk - bentuk sains di antaranya yaitu bermain dengan air, dengan kata lain dapat di simpulkan bahwa pembelajaran sains penting untuk perkembangan anak terutama perkembangan kognitif, selain itu dengan adanya penerapan sains guru akan mempermudah dalam mengkombinasikan permainan, karena sains ini biasa di lakukan dalam kehidupan sehari hari, dengan kata lain mempermudah dan menarik pembelajarannya yang akan di lakukan. Pembelajaran sains anak usia dini masih jarang di lakukan padahal pembelajaran ini banyak di temukan sehari-hari oleh anak. Lembar kerja terus di berikan oleh guru dengan berbagai tema dan perkembangan. Di duga dengan pembelajaran sains dengan pendekatan saintifik lebih merangsang kognitif anak terutama sains. Pada tahap praoperasional atau usia 5-6 tahun tumbuh kembang anak masih masa pencarian oleh karenanya ada perbedaan dalam pembelajaran akan lebih banyak rangsangan dan pertanyaan dengan mengunakan pendekatan saintifik, karena anak di beri kesempatan meneliti. Penelitian ini langkah yang di lakukan adalah berawal dari menurut teori Bloom bahwa pembelajaran sains ini meliputi mengingat, memahami, mengaplikasikan, menganalisis, mengevaluasi, mencipta. Dengan pendekatan saintifik aspek pembelajaran sains tersebut sudah terpenuhi, berarti hasil perkembangan kognitif anak terutama sains sudah terpenuhi.

\section{B. Metode}


Penelitian ini menggunakan penelitian kualitatif. Peneliti menggunakan pendekatan kualitatif karena memiliki pertimbangan. Pertama, penelitian kualitatif lebih mudah apabila berhadapan dengan kenyataan jamak atau ganda. Kedua, peneliti ingin menyajkan secara langsung hakikat hubungan antara peneliti dan informan. Ketiga, metode ini lebih peka dan dapat menyesuaikan diri dengan banyak penajaman pengaruh bersama terhadap pola-pola yang dihadapi. Menurut Moleong, L. J. (2010:9). Hal ini sesuai dengan apa yang hendak di capai oleh peneliti yang ingin menalaah dan memahami sikap, pandangan, dan prilaku baik individu maupun sekelompok orang yang tidak dapat di ukur hanya dengan angkaangka saja. Oleh karena itu penulis menggunakan metode penelitian kualitatif untuk dapat menafsirkan makna dari setiap peristiwa. Desain penelitian ini adalah fenomenal.

Penelitian ini dilakukan pada anak kelompok B usia 5 - 6 tahun di RA Annur Assalafy Tumpang Pacarkeling Kejayan Pasuruan yang berjumlah 25 anak. Waktu penelitian dilakukan dimulai tanggal 17 Januari 2019 s.d 15 Februari 2019.

Ada tiga cara yang di gunakan sebagai teknik pengumpulan data pada penelitian ini yaitu wawancara, observasi dan dokumentasi. (1) Wawancara bentuk wawancara yang digunakan bersifat terstruktur, terbuka dan langsung ke sumbernya, serta menggunakan penjadwalan agar pada saat wawancara tidak terkesan mendadak yang mengakibatkan data yang diambil tidak maksimal. Sedangkan alat bantu yang di gunakan pada saat wawancara adalah dengan merekm dengan hp supaya data hasil wawancar terekam secara akurat.

Tabel 1. Kisi-Kisi Wawancara

\begin{tabular}{|l|l|l|}
\hline Tujuan peneitian & Faktor & Indikator \\
\hline $\begin{array}{l}\text { Untuk mengkaji } \\
\text { implementasi }\end{array}$ & $\begin{array}{l}\text { Perencanaan } \\
\text { pembelajaran }\end{array}$ & RPPH \\
\cline { 2 - 3 } $\begin{array}{l}\text { pendekatan saintifik } \\
\text { terhadap }\end{array}$ & $\begin{array}{l}\text { Pelaksanaan } \\
\text { pembelajaran }\end{array}$ & Saintifik \\
\cline { 2 - 3 } $\begin{array}{l}\text { kemampuan kognitif } \\
\text { sains anak usia 5-6 } \\
\text { tahun }\end{array}$ & Model pembelajaran & Model pembelajaran \\
\cline { 2 - 3 } & Penilaian hasil belajar & Penilaian hasil belaja \\
\hline
\end{tabular}

(2) Observasi yang dilakukan dalam penelitian ini berkenaan dengan cara mengajar antara guru dan anak di kelompok B usia 5 - 6 tahun di RA Annur Assalafy Tumpang Pacarkeling Kejayan Pasuruan.

Tabel 2. Kisi-Kisi Panduan Observasi

\begin{tabular}{|l|l|l|}
\hline Tujuan penelitian & Kegiatan/ Faktor & Indikator \\
\hline Untuk mengkaji & Perencanaan & a. Guru menyiapkan \\
\hline
\end{tabular}




\begin{tabular}{|c|c|c|}
\hline \multirow{10}{*}{$\begin{array}{l}\text { implementasi pendektan } \\
\text { saintifik terhadap } \\
\text { kemampuan } \\
\text { perkembangan kognitif } \\
\text { sains usia } 5 \text { - } 6 \text { tahun }\end{array}$} & \multirow[t]{2}{*}{ Pembelajaran } & $\begin{array}{l}\text { RPPH buat acuan dalam } \\
\text { pembelajaran? }\end{array}$ \\
\hline & & $\begin{array}{l}\text { b.. Guru menyiapkan } \\
\text { media pembelajaran } \\
\text { dalam proses } \\
\text { pembelajaran? }\end{array}$ \\
\hline & \multirow[t]{2}{*}{ Kegiatan Pendahuluan } & $\begin{array}{l}\text { a. Guru mengkondisikan } \\
\text { suasana belajar yang } \\
\text { menyenangkan? }\end{array}$ \\
\hline & & $\begin{array}{l}\text { b. Guru bercerita tentang } \\
\text { kegiatan yang akan } \\
\text { dilakukan? }\end{array}$ \\
\hline & \multirow[t]{2}{*}{$\begin{array}{l}\text { Kegiatan Inti - } \\
\text { Mengamati }\end{array}$} & $\begin{array}{l}\text { a. Guru mengajak anak } \\
\text { untuk melakukan proses } \\
\text { mengamati? }\end{array}$ \\
\hline & & $\begin{array}{l}\text { b. Apakah guru sudah } \\
\text { menggunakan media } \\
\text { saat mengajar seperti } \\
\text { menggunakan gambar } \\
\text { atau media yang sesuai } \\
\text { dengan kegiatan tsb? }\end{array}$ \\
\hline & \multirow[t]{2}{*}{ - Menanya } & $\begin{array}{l}\text { a. Guru mengajak anak } \\
\text { untuk melakukan proses } \\
\text { menanya? }\end{array}$ \\
\hline & & $\begin{array}{l}\text { b. . Dalam pembelajaran } \\
\text { berlangsung apakah } \\
\text { guru sudah merangsang } \\
\text { siswa, sehingga anak } \\
\text { bisa memiliki rasa } \\
\text { ingintau (Menanya)? }\end{array}$ \\
\hline & \multirow[t]{2}{*}{$\begin{array}{l}\text { Mengumpulkan } \\
\text { informasi/ mencoba }\end{array}$} & $\begin{array}{l}\text { a. Guru memberi } \\
\text { kesempatan pada anak } \\
\text { untuk mencoba, } \\
\text { mendemonstrasikan, } \\
\text { melakukan eksperimen, } \\
\text { mengumpulkan } \\
\text { informasi dari berbagai } \\
\text { sumber? }\end{array}$ \\
\hline & & $\begin{array}{l}\text { b. Apakah guru mampu } \\
\text { menstimulasianak untuk } \\
\text { mengumpulkan }\end{array}$ \\
\hline
\end{tabular}




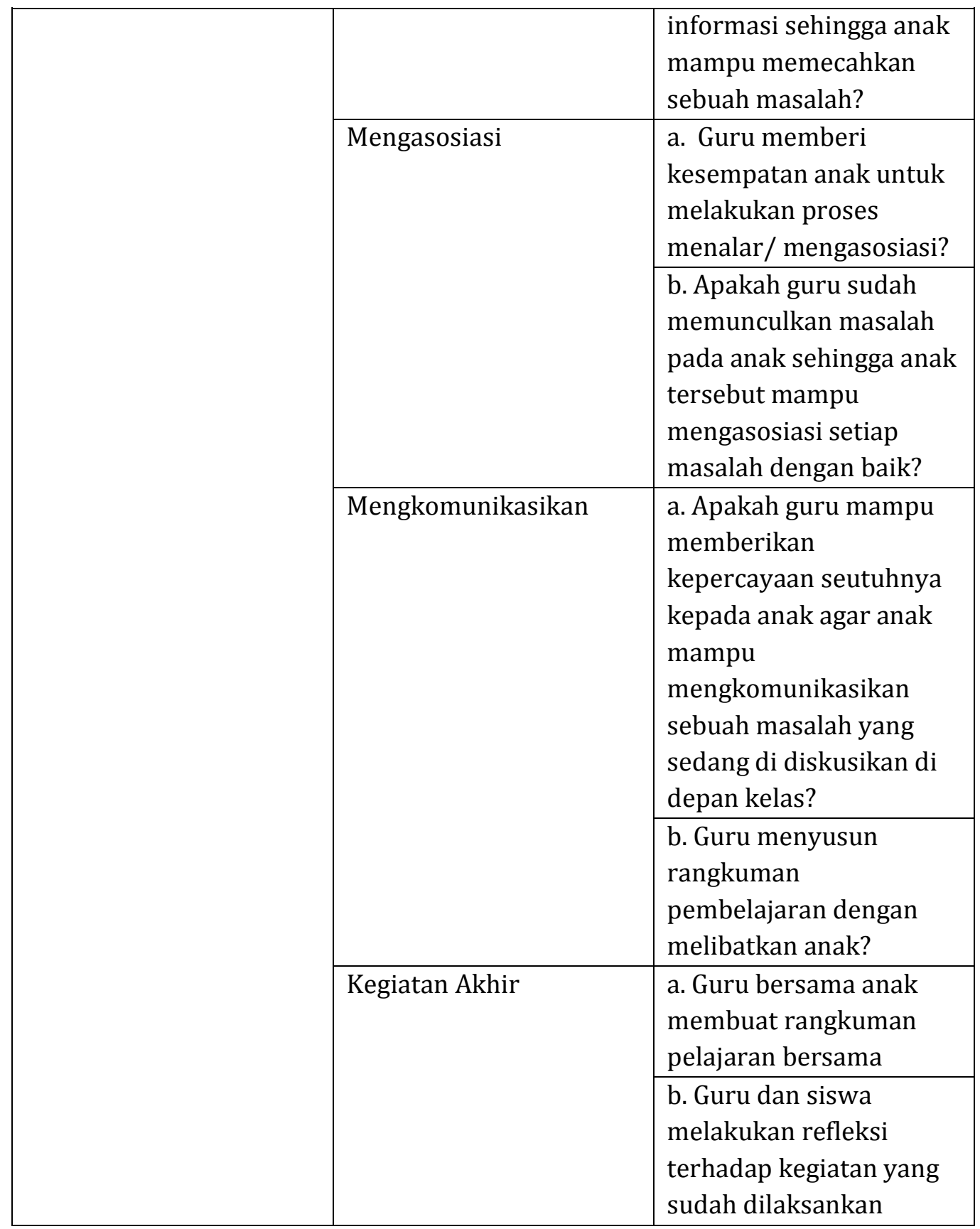

(3) Dokumentasi juga digunakan dalam pengumpulan data dalam penelitian ini, adapun yang didokumentasikan berkenaan dengan dokumen Rencana pelaksanaan pembelajaran harian (RPPH) yang dibuat oleh guru, serta dokumen saat pembelajaran berlangsung maupun foto-foto yang diambil saat pengambilan data.Agar data yang diambil dapat terjamin keasliannya maka yang menjadi instrumen dalam penelitian ini adalah penulis sendiri sebagai alat pengumpul data. 
Tabel 3. Kisi-Kisi Pedoman Dokumentasi

\begin{tabular}{|l|l|l|l|l|}
\hline \multirow{2}{*}{ NO } & \multirow{2}{*}{ Nama dokumen } & \multicolumn{2}{|c|}{ hasil } & Keterangan \\
\cline { 3 - 5 } & & ada & tidak & \\
\hline 1 & Saat pembelajaran & & & \\
\hline 2 & $\begin{array}{l}\text { Lembar Penilaian } \\
\text { siswa }\end{array}$ & & & \\
\hline 3 & RPH & & & \\
\hline
\end{tabular}

Hal ini dilakukan agar data yang di ambil sesuai dengan kenyataan yang ada dilapangan tidak sebatas pada wawancara, observasi, dan dokumentasi yang telah di buat, melainkan bias meluas dan berusaha menggali lebih dalam. Data yang muncul dalam penelitian berupa kata-kata bukan merupakan angka-angka, yang dikumpulkan melalui hasil wawancara, observasi maupun dokumentasi. Teknik analisisnyapun tetap menggunakan kata-kata, yang disusun ke dalam teks yang mendapat perluasan makna. "Miles dan Huberman mengemukakan bahwa aktivitas dalam analisis data kualitatif dilakukan secara interaktif dan berlangsung terus menerus sampaituntas, sehingga datanya sudah jenuh", Menurut Sugiyono (2013:337). Aktivitas dalam analisis data terdiri atas tiga alur kegiatan yang terjadi secara bersamaan, yaitu: reduksi data, penyajian data, dan penarikan kesimpulan/verifikasi. (a) Pengumpulan data Dilaksanakan dengan cara pencarian data yang diperlukan terhadap berbagai jenis data dan bentuk data yang ada dilapangan, kemudian melaksakan pencatatan data di lapangan.Pengumpulan data dilaksakan dengan cara melakukan wawancara, observasi, dan dokumentasi untuk mendapatkan data yang lengkap. Adapaun pengumpulan data dalam bentuk dokumen diperoleh dari laporan program dan profil sekolahyang bersangkutan. (b) Reduksi data yang diperoleh selama pengumpulan data di lapangan yang jumlahnya cukup banyak, perlu dicatat secara rinci dan teliti. (c) Penyajian data setelah dilakukan reduksi data, maka langkah selanjutnya yaitu menyajikan data. Data yang terkumpul kemudian dipilah dan dikelompokkan berdasarkan kisi-kisi yang telah dibuat, berbentuk teks yang bersifat naratif. Adapun rencana data yang akan disajikan mengenai; "Analisis Implementasi Pendekatan Saintifik terhadap kemampuan kognitif sains anak usia 5 - 6 tahun di RA Annur Assalafy “,meliputi : (1) Faktor yang berasal dari guru, (2) Faktor yang berasal dari anak dan (3) Halhal yang dianggap baruyang merupakan permasalahan yang penting. (d) Langkah berikutnya adalah penarikan kesimpulan. Kesimpulan dalam penelitian ini berupa analisis guru RA kel. B dalam penggunaan pendekatan saintifik saat pembelajaran di kelas kelompok B. 


\section{Hasil dan Pembahasan}

Berdasarkan data-data yang didapatkan oleh peneliti, maka pembahasan hasilnya akan dijelaskan dalam 2 bagian yaitu (a) perencanaan pembelajaran (b) pelaksanaan pembelajaran. Berikut pembahasan dari hasil penelitian tersebut (1) Perencanaan pembelajaran tentang perencanaan pembelajaran terlihat jelas dari penjelasan di atas bahwa peneliti tidak mengalami kesulitan dalam menyusun $\mathrm{RPPH}$ ataupun dalam pembuatan media pembelajaran di kelas, peneliti juga melihat RPPH milik sekolah yang awalnya memang sudah benar karna guru di sekolah RA sudah mendapatkan pelatihan-pelatihan dari pihak sekolah maupun pemerintah . (2) Pelaksanaan pembelajaran tentang pelaksanaan pembelajaran di kelas yang pada awalnya di sekolah guru RA menggunakan pembelajaran dengan sistem sentra sudah bagus namun dalam kegiatan kognitif sains guru RA masih menggunakan media seperti menghitung gambar, menghitung benda-benda di sekitarnya dengan menggunakan media dan lain-lain, sehingga anak kelompok B sudah banyak yang bisa menebak hasil yang akan di dapatkan sehingga antusias dan minat anak untuk pembelajaran kognitif sangat kurang oleh karena itu peneliti melakukan kegiatan kognitif yang lebih berinovasi yaitu kegiatan kegiatan kognitif sains dan sesuai dengan penjelasan di atas kegiatan kognitif sains yang di alkukan oleh peneliti terbukti sangan membuat anak antusias dan minat anak dalam kegiatan kognitif terutama sains sangan bagus sehingga target dalam perekembangan anak bisa terpenuhi, adapun penjelasannya sebagai berikut : (a) Kegiatan pendahuluan peneliti mengajak anak untuk senam setelah itu mengajak anak untuk bermain kereta api dengan memutari halaman sekolah sambil bernyanyi setelah itu peneliti mengajak anak untuk membuat cicle time dengan materi doa-doa dan menyanyi dan bercerita tentang kegiatan yang akan dilakukan di kegiatan inti.

Dari hasil penelitian Pada kegiatan pendahuluan peneliti sudah melaksanakan kegiatan pendahuluan secara menyeluruh dan baik. (b) Kegiatan inti kegiatan inti merupakan proses pembelajaran yang menggunakan pendekatan saintifik, menurut Alfared De Vito (dalam Abdul Majid dan Chaerul Rochman, 2015:3), "pendekatan saintifik merupakan pembelajaran yang mengadopsi langkah-langkah saintis ", dari hasil penelitian, peneliti sudah melakukan kegiatan pembelajaran dengan menggunakan pendekatan saintifik yaitu pembelajaran dengan menggunakan 5 pemahaman (mengamati, menanya, mengumpulkan informasi / mencoba, menalar/mengsosiasi, membuat kesimpulan dan mengkomunikasikan ), dengan penjelasannya sebagai berikut:

(1) Mengamati dalam kegiatan mengamati peneliti mengajak anak untuk mengamati dengan melihat proses tenggelam, terapung, mengambang telur yang 
di peraktekkan oleh peneliti sesuai dengan Abdul Majid dan Choirul Rochman (2015:77) yang menyatakan "kegiatan mengamati, guru membuka secara luas dan bervariasi kesempatan peserta didik untuk melakukan pengamatan melalui kegiatan: melihat, menyimak, mendengar, dan membaca". Menurut peneliti dengan mengikuti prinsip 5M maka hasilnya akan lebih baik. Dari pernyataan diatas ini bahwa peneliti telah menerapkan $\mathrm{M}$ yang pertama dengan baik begitu pula dengan anak yang antusias dengan melihat proses tenggelam, mengambang, mengapung, yang dilakukan peneliti saat pembelajaran didalam kelas sehingga secara tidak sadar anak telah melakukan kegiatan mengamati.

(2) Menanya mengenai kegiatan menanya menurut Majid, A. dan Rochman, C. (2015:79), "salah satu fungsi bertanya yaitu membangkitkan rasa ingin tahu, minat, dan perhatian peserta didik tentang suatu tema atau topic pembelajaran". Serta Menurut Daryanto $(2014 ; 64)$, pada kegiatan menanya guru membuka kesempatan secara luas kepada anak untuk bertanya mengenai apa yang sudah dilihat, disimak, dibaca, atau dilihat. Sesuai hasil penelitian dimana siswa dipancing rasa ingin tahunya supaya bertanya, sehingga prinsip $5 \mathrm{M}$ dapat terlaksana dengan baik dan menghasilkan pembelajaran yang lebih baik. Pada kegiatan menanya peneliti sudah melakukan kegiatan menanya dengan baik dan kompetensi yang diharapkan dalam kegiatan menanya ini adalah mengembangkan kreativitas, rasa ingin tahu, sudah tercapai sesuai dengan penjelasan di atas sehinggan penerapan $\mathrm{M}$ yang ke dua sudah dilakukan dengan hasil yang baik, anak-anak sangat antusias dalam melakukan kegiatan menanya tersebut.

(3) Mengumpulkan inforasi/mencoba kegiatan mencoba atau mengumpulkan informasi menurut Majid, A. dan Rochman, C. (2015:90) "aplikasi metode eksperimen atau mencoba dimaksudkan untuk mengembangkan berbagai ranah tujuan belajar yaitu sikap, keterampilan dan pengetahuan". Dari hasil penelitian ini terlihat saat anak mencoba sendiri kegiatan memasukkan telur ke setiap gelas yang berbeda sehingga penerapan M yang ke tiga tercapai dengan baik dan Kompetensi yang diharapkan dalam kegiatan megumpulkan informasi ini adalah mengembangkan sikap teliti, sopan, menghargai pendapat orang lain, mampu berkomunikasi, menerapkan kemampuan mengumpulkan informasi melalui berbagai cara yang dipelajari.

(4) Menalar/mengasosiasi kegiatan mengasosiasi dalam (Permendikbud Nomor 81A Tahun 2013), adalah memproses informasi yang sudah dikumpulkan baik terbatas dari hasil kegiatan mengumpulkan eksperimen maupun hasil dari kegiatan mengamati dan kegiatan mengumpulkan informasi. Pengolahan informasi yang dikumpulkan bersifat menambah keluasan dan kedalaman sampai kepada pengolahan informasi yang bersifat mencari solusi dari berbagai sumber. 
Menambahkan, menurut Abdul Majid dan Choirul Rochman (2015: 85) "associating atau mengasosiasi merupakan padanan dari menalar". Dari hasil penelitian dapat diambil kesimpulan terhadapaspek mengasosiasi bahwa peneliti sudah melakukan kegiatan mengasosiasi saat pembelajaran di kelas. Kompetensi yang dikembangkan dalam proses mengasosiasi/mengolah informasi adalah mengembangkan sikap jujur, teliti, disiplin, taat aturan, kerja keras, mampu berfikir secara kreatif dan dapat menyimpulkan kegiatan yang telah dilakukan.

(5) Membuat kesimpulan dan mengkomunikasikan kegiatan mengkomunikasikan menurut Abdul Majid dan Choirul Rochman (2015:92) "pada kegiatan akhir diharapkan peserta didik dapat mengkomunikasikan hasil kegiatan yang telah dilakukan. Dari hasil penelitian penliti sudah melaksanakan kegiatan mengkomunikasikan dengan baik di lihat dari penelitian di atas bahwa anak-anak sangat antusias dan bersemangat dalam melakukan kegiatan mengkomunkasikan. Kompetensi yang diharapkan dalam kegiatan ini adalah mengembangkan sikap jujur, teliti, toleransi, kemampuan berpikir sistematis, mengungkapkan pendapat dengan singkat dan jelas, dan mengembangkan kemampuan berbahasa yang baik dan benar. (c) Kegiatan penutup di kegiatan penutup ini peneliti melakukan kegiatan evaluasi dan memberi pertanyaan-pertanyaan seputar kegiatan tersebut. Peneliti juga memberi penilaian berupa bintang kepada anak yang bisa menjawab pertanyaan-pertanyaan yang peneliti ajukan dan memotivasi anak untuk tetap semangat. Peneliti juga mengajak anak-anak untuk bernyanyi dan membaca doa dan menginformasikan untuk kegiatan besok yang akan di lakukan. Sesuai dengan penjelasan tadi bahwa peneliti sudah melakukan kegiatan penutup dengan baik.

\section{Simpulan}

Berdasarkan analisis data dan pembahasan dalam penelitian ini dapat disimpulkan bahwa dengan mengimplementasi pendekatan saintifik terhadap kemampuan kognitif sains anak usia 5 - 6 tahun dapat mempengaruhi hasil belajar anak pada kelompok B terutama pada perkembangan kognitif sains. secara khusus, pelaksanaan pendekatan saintifik dalam pengembangan kemampuan kognitif sains anak terlaksana dengan cukup baik di kegiatan pembelajaran meskipun belum maksimal karna pelaksanaanya adalah hal yang baru di sekolah pembelajaran PAUD. Perkembangan kognitif sains anak mencakup aspek pola pikir anak seperti mengamati objek dan berbagai ekspeimen di sekitarnya, mengembangkan keterampilan sains dasar seperti melakukan pengamatan, mengkomunikasikan hasil pengamatan, mengembangkan rasa ingin tahu dll. Perkembangan kognitif sains anak usia 5-6 tahun mengarah pada perekmbangan yang sangat baik dan berkembang sesuai harapan. Terdapat hubungan pendekatan saintifik dan kognitif 
sains anak, dengan mengimplentasikan pendekatan saintifik memunculkan motivasi anak untuk belajar melalui bermain. Dengan mengimplementasikan pendekatan saintifik maka perkembangan kognitif sains anak di RA Annur Assalafy dapat di tingkatkan.

\section{Daftar Rujukan}

Daryanto. (2014).Pendekatan Pembelajaran Saentifik Kurikulum 2913. Yogyakarta: Gava Media.

Hamdani, (2011). Strategi belajar mengajar. Bandung: Pustaka Setia.

Hosman.(2014). Pendekatan Saintifik Dan Kontekstual Dalam Pembelajaran Abad 21. Bogor: Ghalia Indonesia.

Imas, Kurniasih \& Sani, Berlin. (2014). Implementasi Kurikulum 2013 Konsep \& Penerapan. Surabaya: Kata Pena.

Moleong, L. J.(2010). Metodologi Penelitian Kualitatif. Bandung:PT. Remaja Rosdakarya

Majid, Abdul dan Rochman, C. (2015). Pendekatan Ilmiah dalam Implementasi Kurikulum 2013. Bandung : Remaja Rosdakarya.

Majid, A. (2013). Strategi dan model pembelajaran. Yogyakarta: Aswaja Pressindo

Mulyasa, E. (2013). Pengembangan dan Implementasi Kurikulum 2013. Bandung: PT Remaja Rosdakarya

Mulyasa, E. (2015). Guru dalam Implementasi Kurikulum 2013. Bandung: PT. Remaja Rosdakarya.

Muzamiroh, L. M. (2013). Kupas Tuntas Kurikulum 2013. Jakarta : Kata Pena.

Permendiknas . (2008). Undang-undag SISDIKNAS (SistemPendidikan Nasional) (UU RI No. 20 Th. 2003). Jakarta : Sinar Grafika.

Permendibud. (2013).Peraturan Menteri Pendidikan dan Kebudayaan Nomor.69 Tahun 2013 Tentang Kerangka Dasar dan Struktur Kurikulum Sekolah Menengah Atas/ Madrasah Aliyah Jakarta: Permendikbud.

Rusman. (2011).Model-model Pembelajaran Mengembangkan Profesionalisme Guru. Jakarta: PT.Rajagrafindo Persada.

Sani, A. R. (2014). Pembelajaran Saintifik untuk Implementasi 2013.PT Bumi Aksara Sagala, S. (2010). Konsep dan Makna Pembelajaran. Bandung : Alfabeta.

Shoimin, A. (2014). Model Pembelajaran Inovatif dalam Kurikulum 2013. Yogyakarta: Ar-Ruzz Media.

Sugiyono. (2013). Metode Penelitian Pendidikan Pendekatan Kuantitatif, Kualitatif, dan R\&D. Bandung: Alfabeta.

Suyono dan Hariyanto.(2012). Belajar dan Pembelajaran. Bandung: PT Rpsdakarya Remaja.

Tim Pustaka Yustisia. (2007). Panduan Lengkap KTSP (Kurikulum Tingkat Satuan Pendidikan). Yogyakarta: Pustaka Yustisia 